\title{
A CLASSIFICATION OF TECHNIQUES FOR CONTROLLING SITUATIONAL PRECIPITATORS OF CRIME
}

\author{
Richard Wortley ${ }^{1}$
}

To cite:

Wortley, R. (2001). A classification of techniques for controlling situational precipitators of crime. Security Journal, 14(4), 63-82 


\begin{abstract}
The most widely known classification of situational crime prevention techniques is that presented by Clarke ${ }^{2}$. The latest version of the classification proposed 16 techniques for preventing crime through opportunity reduction. The present paper suggests a complementary classification of 16 techniques for controlling situational precipitators of crime. The new classification is based on the argument that there are two distinct situational forces acting upon potential offenders -- the perceived costs and benefits of intended criminal acts (the basis of Clarke's classification) and factors that may induce individuals to commit crimes that they would not have otherwise considered (the basis of the present classification).
\end{abstract}

Key Words: Situational crime prevention; Crime precipitators; Opportunity reduction; Rational choice perspective; Person-situation interaction 


\section{Introduction}

Clarke's ${ }^{3}$ classification of situational crime prevention techniques has become highly influential in defining the nature and scope of the crime prevention task. In the latest 16category version of the classification ${ }^{4}$ four basic strategies were described -- increasing perceived effort, increasing perceived risk, reducing anticipated rewards, and removing excuses --with four specific techniques listed under each strategy. The proposed techniques involve altering immediate environments in ways that reduce opportunities for crime. Underpinning this approach is the rational choice perspective ${ }^{5}$ which portrays potential offenders as utility-maximisers who weigh up the costs and benefits of illegal behaviour then act on the basis of the outcome of this calculus. Crime prevention is viewed in terms of increasing the perceived costs and reducing the perceived benefits of offending so that criminal behaviour might be judged by the potential offender to be an unattractive option. Through the popularity of Clarke's classification, situational crime prevention and opportunity-reduction have become largely synonymous.

However, Wortley ${ }^{6}$ has argued that opportunity reduction is only half of the situational crime prevention story. The person-situation interaction -- the theoretical premise upon which situational crime prevention ultimately rests -- is more complex than the rational choice and opportunity-reduction approaches suggest. Opportunity implies only that certain situational factors make it easy for the individual to follow a course of action that will deliver benefits. However, an examination of psychological and criminological theories that incorporate a role for the immediate environment suggests that in many cases situations are important not because they provide information about the likely 
outcome of a behaviour (which is the basis of opportunity-reduction) but because they actively bring on behaviour. That is, whereas the term opportunity-reduction assumes the existence of a motivated or at least ambivalent offender who is ready to give in to criminal temptations, it is argued that the motivation to commit crime may itself be situationally dependent.

Consider, for example, the case of a prisoner who is subjected to excessively frustrating prison conditions (an oppressive regime, lack of choice about day-to-day decisions, provocative treatment by guards and so forth). The prisoner may respond to such frustrations with some form of aggression (assaulting a guard or destroying property). The obvious situational prevention strategy in this case is to change prison conditions that reduce frustrations. However, such an approach cannot fairly be categorised as reducing opportunities in the usual sense of that word, and indeed, attempting to further reduce opportunities (imposing more restrictions on the prisoner's behaviour) may well make the situation worse. Rather, reducing frustrations seeks to eliminate conditions that precipitated the behaviour.

Distinguishing between opportunities and precipitators is more than an exercise in semantics. At a theoretical level, consideration of precipitating influences on behaviour provides a better defence against the claim that situational strategies displace crime but do not prevent it. Opportunity-reduction is vulnerable to the criticism that altering the environment at one location will simply encourage the potential offender to seek out a more conducive location. However, the notion that situations can help induce behaviour, 
and not just block it, better explains why displacement effects frequently do not occur. At an applied level, the term opportunity-reduction has encouraged an undue focus on target hardening techniques by both practitioners and critics, and has contributed to the restricted appeal of the situational approach. Consideration of precipitating influences on behaviour encourages crime prevention practitioners to think divergently and opens the way for new and often 'softer' prevention strategies.

Wortley ${ }^{7}$ proposed a two-stage model for conceptualising the relationship between precipitating influences and opportunities (see Figure 1). The first stage of the model involves situational forces that precipitate criminal conduct. Behaviour may be entirely avoided if relevant situational precipitators are adequately controlled. In the event that behaviour is initiated, then, in the second stage of the model performance of that behaviour is subject to consideration of the costs and benefits that are likely to follow. The absence of appropriate disincentives or constraints will permit or encourage behaviour while appropriate disincentives or constraints will prevent or discourage behaviour. There are two 'loops' in the model. First, over-attention to the control of precipitating factors may necessarily preclude the use of adequate opportunity-reducing strategies, and so permit the performance of unwanted behaviour. Second, over-control at the opportunity-reduction stage may be equally counterproductive and feed back to increase precipitating pressures on behaviour. Returning to the example of prison conditions, it was argued that too many restrictions on behaviour (excessive opportunityreduction) might generate frustration and increase levels of expressive violence. Equally, 
however, moving too far in the other direction -- excessive easing of restrictions in an attempt to reduce frustrations -- may lead to a loss of institutional control.

Figure 1 about here

Clarke's classification of situational prevention techniques may be fitted into the second stage of the two-stage model. The purpose of this current paper is to set out a classification of 16 precipitation-control techniques -- the first stage of the model -which parallels Clarke's classification. It is not suggested that the classification presents a new theory of criminal behaviour. Rather, the classification is an eclectic model that draws together insights on the person-situation interaction as presented in a range of existing psychological and criminological perspectives (notably, behaviour theory, social learning theory, neutralization theory, social psychology and environmental psychology). For the sake of brevity and to avoid repetition these theoretical roots are not discussed in any depth in this paper. The focus in this paper is on providing examples from the literature to demonstrate the efficacy of the various techniques. A more detailed discussion of the theoretical bases for the classification can be found elsewhere ${ }^{8}$.

\section{The 16 Techniques}

Wortley ${ }^{9}$ suggested four ways that situations might precipitate criminal responses. Situations can present cues that prompt an individual to perform criminal behaviour; they can exert social pressure on an individual to offend; they can weaken moral prohibitions and so permit potential offenders to commit illegal acts; and they can produce emotional 
arousal that provokes a criminal response. These categories in turn suggest four strategies for controlling situational precipitators of crime -- 'controlling prompts', 'controlling pressures', 'reducing permissibility', and 'reducing provocations' -- each involving four techniques (Table 1).

Table 1 about here

\section{Controlling prompts}

Situations may present salient cues to potential offenders that prompt criminal behaviour. The concept of prompting is based on learning theory's stimulus-response (S-R) principle that holds that virtually all action must be initiated by an appropriate cue in the immediate environment. These cues are often subtle and individuals need not necessarily engage in any conscious deliberation about them, nor do they even need to be aware of their effects. In everyday terms, environmental cues tempt us, jog our memory, create expectations, evoke moods, stimulate us, warn us, and set examples for us to follow. In theoretical terms, environmental cues include eliciting stimuli, discriminative stimuli, models and expectancy cues. The four corresponding techniques described in this section are 'controlling triggers', 'providing reminders', 'reducing inappropriate imitation', and 'setting positive expectations'.

Controlling triggers Controlling triggers is directed at automatic or reflex responses to environmental conditions. There are many everyday examples where situations trigger physiological or behavioural responses -- viewing erotic images produces sexual arousal, 
the sight of blood makes many people feel nauseous, the smell of food can induce hunger, listening to a familiar piece of music can arouse feelings of nostalgia, and so forth. The so-called weapons effect is an example of a potentially antisocial response to an environmental cue. Berkowitz ${ }^{10}$ found that the sight of weapons could trigger feelings of aggression and facilitate violent behaviour. The weapons effect suggests that guncontrol legislation may be important in not only reducing the opportunities for offenders to use firearms but also in reducing the tendency for people to become aggressive in the first place. Similarly, Veno and Davidson ${ }^{11}$ suggested that the observation by prisoners of armed guards may one factor contributing to prisoner violence, and that changing prison environments in ways that de-emphasise militaristic aspects might reduce violence levels.

Triggers may be particularly important in sex offending. Goldstein et $\mathrm{al}^{12}$ found that sexoffenders were three times more likely to own pornography than were non-sex-offenders, and Marshall ${ }^{13}$ reported that one-third of rapists and child-molesters surveyed claimed to have been incited to offend by viewing pornography. Such research provides the rationale for restricting or censoring violent pornography, particularly that portraying victims enjoying abuse ${ }^{14}$. But sex triggers need not involve explicit pornography. Paedophiles may be sexually aroused simply by the sight of children ${ }^{15}$. Laws that prohibit convicted paedophiles from taking jobs that bring them into contact with children both reduce opportunities for offending and help potential offenders to keep their sexual desires in check. People can also manage their own immediate environments in order to avoid unwanted triggers. In relapse prevention, sex offenders are taught to identify and deal with high-risk situations that might precipitate sexual offending. For example, a 
paedophile might avoid taking a short cut through a park where he knows that children often play ${ }^{16}$. A similar rationale can be used to help people self-manage other repetitive behaviours such as drug and alcohol abuse ${ }^{17}$.

Providing reminders Environmental cues often serve to remind people of appropriate standards of behaviour. Reminders may be introduced into an environment to encourage or discourage targeted behaviours. Written signs are the most obvious example of situational reminders. Signs are ubiquitous features of the landscape and research suggests they can be effective in influencing a range of behaviours. Geller et $\mathrm{al}^{18}$ found that honesty prompts attached to self-service newspaper racks reduced thefts by $15 \%$. Weinstein et al $^{19}$ reported that seat-belt reminder messages in parking lots and on car dashboards increased seat-belt usage by 31\%. Several studies have reported that warning signs significantly reduced illegal parking in spaces reserved for disabled drivers ${ }^{20}$. Watson ${ }^{21}$ found that anti-graffiti signs in college restrooms resulted in an immediate cessation of vandalism, a result maintained in a 3-month follow-up. Anti-littering signs have been found to significantly reduce littering in a variety of locations ${ }^{22}$, while Geller et $\mathrm{al}^{23}$ obtained reductions in littering when litter disposal instructions were printed on the bottom of advertising fliers handed out at a supermarket.

Reminders need not involve explicit warnings or instructions. Relevant objects can also prompt appropriate behaviour and in some cases may be more salient than signs. For example, cardboard cut-outs of uniformed guards placed in the aisles of stores are designed to startle the unsuspecting shopper and present a visual reminder not to steal. 
Harrell $^{24}$ found that motorists were significantly more likely to yield at a marked crossing for a pedestrian with a cane than for a pedestrian without a cane, particularly if a sign indicating a recent fatality was also posted. Strategically placed litter bins and ashtrays are effective in prompting people not to litter ${ }^{25}$. Decorating receptacles to make them more prominent encourages even greater compliance ${ }^{26}$. Symbolic territorial markers -low fences, shrubs, changes in surface texture, personal possessions and so forth -- can also be considered types of reminders signalling to potential intruders not to trespass ${ }^{27}$. Brown and Altman ${ }^{28}$ found that houses with territorial displays and symbolic boundaries suffered fewer burglaries than houses lacking such displays and boundaries.

Reducing inappropriate imitation The observation of someone committing a crime can precipitate imitation. Bandura ${ }^{29}$ showed that children who observed other children engaging in aggressive play were likely themselves also to play aggressively. Lefkowitz, Blake and Mouton ${ }^{30}$ demonstrated that a pedestrian crossing the street against a red light readily induced others to follow. Skinner and Fream ${ }^{31}$ found that computer crime among college students was positively correlated with the extent to which students observed their teachers engaging in illegal computer activity. Similarly, when work supervisors engage in theft from the organisation, subordinates are more likely to also engage in theft $^{32}$. Models for imitation do not have to appear in person but can be represented symbolically in the mass media. The incidence of suicide has been found to increase immediately following the portrayal of suicide in popular television programs ${ }^{33}$. Positive correlations have been found between the viewing of television violence by children and concurrent measures of aggression ${ }^{34}$. Phillips ${ }^{35}$ reported surges in delinquent homicides 
in the three days following the televising of major boxing matches. Surette ${ }^{36}$ presented a number of case studies of copycat crimes inspired by television programs.

Reducing inappropriate imitation may involve increasing the exposure of potential offenders to prosocial models or restricting their opportunity to imitate models performing antisocial acts. Roggenbuck and Passineau ${ }^{37}$ found that school children on a nature field trip who observed the instructor pick up a piece of litter subsequently picked up $90 \%$ of the litter planted along the trail. Similarly, supervisors can reduce employee fraud or other forms of corruption by setting high and conspicuous standards of probity for subordinates ${ }^{38}$. The principle that people will imitate models underpins public education campaigns (litter reduction, anti-smoking and the like) which enlist the endorsement of celebrities. On the other side of the coin, the same principle is used to justify restrictions on the content of television programs, for example, less sensational coverage of crime and suicide stories in news items ${ }^{39}$. In many cases it is the observed result of illegal behaviour which provides the model rather than observation of the act itself. Thus, the cleaning of graffiti ${ }^{40}$, the rapid repair of vandalism ${ }^{41}$ and the clearing of litter ${ }^{42}$ help restrict the performance of imitative behaviours.

Setting positive expectations The expectations that an individual has about a situation can greatly influence how they behave in that situation. Desirable behaviour may be prompted by setting positive expectations for potential offenders. Expectations in turn can be created by manipulating relevant situational cues. For example, Graham and Homel $^{43}$ argued that levels of nightclub violence were related to the reputations that the 
nightclubs had acquired, and that these reputations were partly determined by physical characteristics of the premises (level of cleanliness, standard of furnishings and so forth). Patrons visited certain nightclubs anticipating that they would be involved in violent incidents and this expectation acted as a self-fulfilling prophecy. Gentrifying the decor of violent nightclubs signals that non-violent behaviour is now expected from patrons. A similar rationale has been applied in the prison context. The use of 'soft' domesticquality furnishings in prisons can reduce vandalism by providing expectancy cues that prompt prisoners to take care of their living environment, whereas 'vandal-proof' furnishings may offer an irresistible challenge to prisoners ${ }^{44}$. The contagious effect of 'broken windows ${ }^{45}$ can also be explained in terms of expectancy. Signs of environmental decay and neglect -- litter, vandalism, dilapidated housing and so forth -- convey a message of lawlessness that invites criminal activity ${ }^{46}$. Urban renewal and other environmental beautification programs may be successful crime prevention strategies not just because they increase the commitment of residents to guardianship but also because they alter the expectations of potential offenders.

\section{Controlling pressures}

Situations may exert social pressure on individuals to perform inappropriate behaviour. A fundamental premise of social psychology is that human behaviour is strongly influenced by the expectations and demands of others and that people therefore behave differently in company than when alone. In particular, individuals are subject to pressures to conform to group norms, to obey the instructions of authority figures, to comply with requests and persuasive arguments, and to submerge their identity in a crowd. The four prevention 
techniques corresponding to these pressures are 'reducing inappropriate conformity', 'reducing inappropriate obedience', 'encouraging compliance', and 'reducing anonymity'.

Reducing inappropriate conformity Conformity refers to the tendency for individuals to adopt group norms and standards of behaviour, even when these contradict personally held beliefs and values. Peer pressure to conform is commonly thought to be an important factor in delinquency ${ }^{47}$. Parents screen their children's associates in a common sense attempt to filter out undesirable influences and to prevent their children getting involved with the 'wrong crowd ${ }^{48}$. Attempts can also be made to bolster independence in young people. Along these lines, Kallis and Varnier ${ }^{49}$ recommended that the most effective antishoplifting signs are 'Make a choice on your own - don't shoplift'. The school is the site for a great deal of peer pressure. Dale ${ }^{50}$ reported that there is less bullying in mixed-sex schools than in boys-only schools, suggesting that that the presence of girls helps create less aggressive social norms. Crime and violence within schools may also be reduced by altering patterns of contact and interaction among members of delinquent cliques ${ }^{51}$. Troublesome students can be dispersed and placed within groups of non-delinquent students in the hope that pro-social conformity will take place.

Adults are not immune from conformity effects. Corruption within organisations is a good example of the power of conformity to induce illegal behaviour. A new employee entering an organisation in which corrupt practices are common faces social pressures from co-workers to also engage in those practices ${ }^{52}$. Greenberg ${ }^{53}$ suggested rotating workers so that stable groups did not form making it difficult for inappropriate group 
norms to develop. Addis ${ }^{54}$ reported that the provision of an anonymous hotline gave workers a safe avenue to challenge entrenched organisational norms and led to a reduction in theft and sexual harassment. The prison environment also exerts powerful pressures for conformity. One way to alter undesirable prison norms is to manipulate the composition of the prison population. For example, Mabli et $\mathrm{al}^{55}$ found that violence decreased in a young-person's prison after older prisoners were introduced to provide a stabilising influence. Similarly, less violence has been reported for gender-mixed prisons than single-gender prisons ${ }^{56}$. Dispersing prison gang members has also been effective in reducing prison violence ${ }^{57}$.

Reducing inappropriate obedience Obedience is the following of a direct command issued by someone perceived to possess legitimate authority. Obedience to authority has been widely used to explain atrocities perpetrated by military regimes, such as the extermination of Jews by the Nazis ${ }^{58}$ and the My Lai massacre ${ }^{59}$. However, inappropriate obedience can also play a role in crimes of a less extreme nature in civilian contexts. Corruption within bureaucracies often entangles subordinates who, motivated by a misguided loyalty to the organisation, act illegally on the orders of their superiors. Examples of crimes of authority include cases of governmental abuses of power ${ }^{60}$, corporate crime $^{61}$, police corruption ${ }^{62}$ and prison officer brutality ${ }^{63}$. Kelman and Hamilton ${ }^{64}$ suggested a number of ways to reduce the undesirable impact of authority. One set of strategies involves the dispersal of authority within organisations and society more generally. Less militaristic and hierarchical regimes -- for example, the creation of semi-independent units within organisations and elements of participatory management -- 
may reduce authoritarian influences. Organisations should also consider rotating leadership positions with relative frequency. Another set of strategies involves empowering individuals to resist unreasonable commands. Clear organisational codes of conduct and departmental policies that provide active support for 'whistle-blowers' may help provide models for appropriate behaviour. Designating someone to act as 'devil's advocate' at every policy-making meeting will ensure that alternative perspectives are heard ${ }^{65}$.

Encouraging compliance Compliance refers to the acquiescence to the direct request of others. Operationally, encouraging compliance involves the use of persuasive communication in order to increase the likelihood of pro-social action. Of equal interest are the conditions under which non-compliance or reactance occurs. A number of studies have shown that signs containing positively-worded persuasive messages are at least as effective as warning signs in encouraging appropriate behaviour ${ }^{66}$. For example, Reiter and Samuel ${ }^{67}$ found the sign 'Pitch in' resulted in as much litter reduction as the sign 'Littering is Unlawful and Subject to a \$10 fine’. Compliance with rules increases when people feel that they have contributed to the formulation of those rules. For example, Snyder et $\mathrm{al}^{68}$ argued that company theft is reduced when employees are consulted about what constitutes legitimate and illegitimate use of company goods. Similarly, compliance increases when people have actively endorsed a given rule. Iso-Ahola and Niblock ${ }^{69}$ found that when campers were asked to sign an anti-littering petition, levels of littering decreased. Generally, too, requests made in person are more effective than impersonal requests ${ }^{70}$. On the other hand, warnings that are too punitive can be counterproductive 
and incite defiance. Bensley and $\mathrm{Wu}^{71}$ found that high-threat anti-alcohol messages resulted in increased alcohol consumption, particularly among heavy drinkers. Similarly, Bushman and Stack ${ }^{72}$ found that authoritative warning labels on violent television programs increased interest in those programs.

Encouraging compliance is an important factor in face-to-face interactions between potential offenders and official guardians such as police, security guards, nightclub crowd controllers, and correctional officers. In many cases these personnel cannot rely solely on their delegated authority to secure compliance, but rather must utilise their personal legitimacy and interpersonal skills in order to hold sway. For example, attempts to gain compliance in prison more often involves enlisting the co-operation of prisoners through negotiation and persuasion than rigidly applying rules or employing coercion and force $^{73}$. Requests and commands that are perceived as fair, consistent and legitimate by prisoners are more likely to be followed than those seen as capricious and unreasonable ${ }^{74}$.

Reducing anonymity Being a member of a group or crowd can cause feelings of anonymity and induce a state of psychological disinhibition. In extreme cases, individuals may become immersed in the group -- deindividuate -- and commit crimes collectively that they would never have carried out singly. The role of anonymity in facilitating antisocial behaviour was demonstrated in the Stanford prison experiment ${ }^{75}$. This research involved the creation of a simulated prison in which male college student volunteers played the parts of prisoners and guards. Shortly into the experiment many guards became brutal and authoritarian. The researchers argued that the guards' uniform, which 
included reflective sunglasses, helped screen the guards' identity and intensified their sense of power and group cohesion.

Reducing anonymity involves promoting a sense of individuality in potential offenders. One way to do this is to restrict symbols that encourage collective identity. The Stanford prison experiment suggests that more informal modes of dress and the wearing of identifying nametags by police, prison guards and so forth may help break down the sense of license that anonymity confers. In a similar vein, school dress codes that ban gang colours may help reduce group-related violence. Special care needs to be taken when dealing with crowds to prevent deindividuation. McKenzie ${ }^{76}$ outlined several techniques for interrupting the development of crowd violence, including dividing the crowd into smaller units, removing crowd leaders, and distracting the attention of the crowd away from the focal point. In a study on preventing rioting at an annual motor cycle race, Veno and Veno ${ }^{77}$ demonstrated the success of co-operative, nonconfrontational methods of crowd control. On the other hand, provocative methods of control -- sometimes a single triggering incident of overpolicing -- can galvanise crowd members and incite collective disorder ${ }^{78}$.

\section{Reducing permissibility}

Situational factors can help distort moral reasoning processes and so permit individuals to engage in normally proscribed behaviour. The human conscience is highly malleable and sensitive to the physical and social context in which behaviour is performed. Given the right circumstances (such as in times of war), ordinary individuals are often capable of 
great brutality. According to neutralization theory ${ }^{79}$, many offenders are not morally committed to their crimes but make excuses that facilitate their criminal involvement. There are four broad categories of moral distortion that may facilitate anti-social behaviour - minimisation of the legitimacy of the moral principle, minimisation of the degree of personal accountability for the behaviour, minimisation of the negative outcomes of the behaviour, and minimisation of the worth or blamelessness of the victim $^{80}$. The corresponding prevention techniques are 'rule setting', 'clarifying responsibility', 'clarifying consequences', and 'personalising victims'.

Rule setting Rule setting is based on the principle that offenders may seek to deny the essential wrongness of their actions, and may even claim the moral high-ground, by contrasting their behaviour with the more heinous behaviour of others (e.g. 'at least I am not a child molester'); focusing on the corruption of those in power (e.g. 'the politicians are the real crooks'); redefining their actions using more palatable language (e.g. 'it is just tax minimisation'); claiming to be serving a higher moral principle (e.g. 'I had to steal to help a friend'); or simply claiming ignorance (e.g. 'I didn't know it was wrong'). Individuals often rely on those around them for guidelines for correct behaviour and may come to accept corrupt practices as normal. For example, support for corrupt activity within organisations may be expressed in sentiments such as 'everybody does it' and 'it goes with the job ${ }^{, 81}$. Formal codes of practice can be used to clarify ethical standards of behaviour and reduce the ability of individuals to exploit rule ambiguity. Parilla et $\mathrm{al}^{82}$ found that the presence of a formal anti-theft policy significantly reduced employee theft rates in retail organisations. Explicit anti-bullying codes have been employed to reduce 
bullying in schools ${ }^{83}$. Similarly, anti-harassment policies and staff induction courses can reduce workplace aggression ${ }^{84}$. Rule setting can also be achieved through signage. For example, 'Shoplifting is Stealing' signs challenge the euphemistic labelling many thieves employ to soften the illicit nature of their behaviour ${ }^{85}$.

Clarifying responsibility Clarifying responsibility is based on the principle that offenders may avoid self-blame for their actions by citing external causal agents (e.g. 'I was unemployed and needed the money’); employing disinhibitors (e.g. 'I was drunk and could not help myself'); claiming a lack of behavioural alternatives (e.g. 'I had no other choice’); or using organisations or superiors to obscure their personal contribution to anti-social acts (e.g. 'I was just doing my job’). The most obvious strategy for clarifying responsibility is controlling alcohol use. Research suggests that the effect of alcohol on behavioural control is cognitive as much as it is physiological and that many people use alcohol precisely in order to provide an excuse for intended anti-social actions ${ }^{86}$. Homel et $\mathrm{al}^{87}$ reported substantial reductions in nightclub violence after a range of serverintervention practices were introduced. Strategies included the ending of discounted drinks and 'happy hour', differential pricing for low-alcohol and full-strength beer, provision of no-alcohol alternatives, and refusal to serve intoxicated patrons.

Offenders can also blame circumstances for their crimes. Clarke and Homel's ${ }^{88}$ suggested technique of improved library checkout as a way of reducing library thefts makes it more difficult for thieves to blame the library for causing them to steal. Personal responsibility for conduct can also be obscured by social systems. Bandura ${ }^{89}$ argued that the division of 
labour within organisations facilitates corruption by allowing individuals to hide behind a collective responsibility (as distinct from helping them avoid detection). Restructuring arrangements so that individuals perform discrete tasks forces them to take personal responsibility for their actions. Similarly, people feel greater responsibility towards property over which they have a sense of ownership. Vandalism in public housing areas is perpetrated not only by intruders but also by residents who feel little personal investment and proprietorial concern. Greater care is taken of estates when tenants are given greater involvement in their management ${ }^{90}$. Likewise, vandalism in institutions can be reduced by promoting in residents a sense of possession over their living areas by allowing freedom in personalising environments with pictures, personal possessions, individual furniture arrangement and so forth ${ }^{91}$.

Clarifying consequences Clarifying consequences is based on the principle that offenders may seek to deny causing harm by portraying the outcome of their actions as being less serious than it really is (e.g. 'I just gave her a few slaps'); denying that any harm was caused (e.g. 'the shop was insured so no-one was hurt'); or even claiming that the consequences were positive (e.g. 'she really enjoyed it'). Using the principle of clarifying consequences, copyright messages on CDs, computer software, videos and so forth emphasise the detrimental effects of piracy to the entertainment industry, and quarantine signs at airports and borders alert travellers to the possible devastation to local agriculture caused by importing undeclared foodstuffs and animal products. Greenberg ${ }^{92}$ noted that often people are unable to appreciate the cumulative effect of small offences. For example, when they steal from employers they comfort themselves with excuses that 'the 
company can afford it' or 'they will never miss it'. Greenberg suggested the technique of public posting to help explain to employees the ultimate costs of stealing. Demonstrating this technique, Carter et $\mathrm{al}^{93}$ found that posting a graph of theft levels in the employee lunchroom increased awareness of the impact on the company and resulted in a reduction of theft. Sometimes, people are simply ignorant of the full effect of their behaviour. Oliver et $\mathrm{al}^{94}$ found providing campers with information on the ecological impact of certain camping practices resulted in a 50\% reduction in vandalism. Similarly, Vander Stoep and Gramann ${ }^{95}$ achieved significant reductions in vandalism at historic sites by providing information on the consequences to the environment of destructive behaviour.

Personalising victims Personalising victims is based on the principle that people find it easier to victimise those who can be stereotyped as sub-human or unworthy (e.g. 'she was just a whore'); those who can be portrayed as deserving of the fate that has befallen them (e.g. 'he had it coming'); or even those who are simply outsiders or anonymous (e.g. 'he is not one of us'). The role of victim-depersonalisation as an intensifier of violence is revealed in Silbert and Pines ${ }^{, 96}$ interviews with prostitutes who had been victims of rape. Victims who had attempted to placate their attacker by telling him that she was a prostitute found instead that he became even more aggressive and brutal. Similarly, Indermaur ${ }^{97}$ found that the offering of resistance by victims during a robbery often had the effect of arousing 'righteous indignation' in the offender and escalating the violence. Indermaur suggested that victims need to adopt non-confrontational techniques in order to avoid providing ‘justification’ for the offender. Appearance, dress and mannerisms may facilitate the process of depersonalisation and increase the chances of victimisation. 
For example, a contributing factor to the brutality displayed by 'guards' in the Stanford prison experiment was the depersonalised status of the prisoners, accentuated by their humiliating and dehumanising uniform and their identification by numbers rather than names. Looking at bullying in schools, Olweus ${ }^{98}$ found that there was a tendency for victims to have distinctive signs of weakness or oddness, for example, deviations in stature, personal hygiene, facial expressions, dress and so forth. Besag ${ }^{99}$ suggested that victims of bullying need to avoid showing anger or distress, and should be taught assertion and social skills.

Derogating intended targets in order to permit victimisation also applies to property and organisations. For example, numerous studies have reported negative correlations between crime within companies and employee job-satisfaction ${ }^{100}$. Employees may steal, become aggressive, or engage in destructive behaviour as an act of revenge to get even for perceived injustices and exploitation perpetrated by the company. In a field experiment, Greenberg ${ }^{101}$ compared theft rates in three companies -- one in which the pay was cut $15 \%$ with no explanation given to employees, one in which pay was cut $15 \%$ and a sensitive explanation was offered, and a control. He found there was significantly more theft in the companies that cut pay than the control, but half as much theft in the company that gave an explanation as the company that did not. Greenberg argued that work-place crime may be reduced by payment of equitable wages and good communication between employers and employees, and suggested the use of a corporate hotline to answer queries about pay. Other suggested strategies include employee share schemes, incentive schemes, better job security and general attention to the welfare of workers as methods of 
increasing attachment to a company and inhibiting justifications for acting fraudulently against it ${ }^{102}$.

\section{Reducing provocations}

Situations can induce stress and provoke an antisocial response, particularly some form of aggression. Aversive emotional arousal can be generated by frustration and environmental factors such as crowding, invasions of privacy, excessive noise, and adverse weather conditions. Four techniques for reducing provocations are 'reducing frustration', 'reducing crowding', 'respecting territory', and 'controlling environmental irritants'.

Reducing frustration Frustration is the emotional state produced when an individual is thwarted in their pursuit of goal-directed behaviour. Studies have highlighted the relationship between frustration and anti-social behaviour in a diversity of situations. Harding et al $^{103}$ found that incidents of road rage correlated with high traffic volume and were initiated by factors such as encounters with slow drivers, other drivers cutting in, and competition for parking spaces. They suggested that driver frustration might be eased by better road design and more efficient traffic flow arrangements. Frustration and stress at work have also been found to be related to increased workplace vandalism and sabotage ${ }^{104}$. Suggested stress-reducing interventions include more positively framed performance appraisals, better communication between management and employees, and greater involvement of employees in planned work-place changes. Homel and Clark ${ }^{105}$ found nightclub violence was related to levels of patron boredom, lack of seating, 
unavailability of food and provocative behaviour of security staff. They argued that better facilities, more entertainment, a greater choice of food, and training for security staff in non-confrontational crowd management tactics would increase patron enjoyment and reduce levels of frustration. Frustration has been claimed to play a role in schoolyard bullying. For example, Boulton ${ }^{106}$ found that bullying increased during wet playtimes and recommended improvements the quality of play facilities to reduce frustration levels of students. In the prison context, Wener and Olsen ${ }^{107}$ argued that it is frustration associated with a lack of control over the environment -- no choice when cell lights are on or off, inability to regulate individual heating and cooling preferences, having to queue for phone calls and meals and so forth -- rather than the oppressive nature of the environment per se that accounts for much of the violence exhibited by prisoners. For example, 57\% of fights in one prison involved disputes over television channels. There are simple situational solutions to many of these problems, such as putting comfort control switches inside cells, providing more televisions, staggering meal times and regulating the length of telephone calls.

Reducing crowding Crowding is the experiential state relating to the perception of spatial limitations. Increased physical, psychological and behavioural problems have been found to occur in a range of high density settings such as college dormitories ${ }^{108}$, nightclubs ${ }^{109}$, naval ships ${ }^{110}$ and prisons ${ }^{111}$. Reducing population density can involve either increasing the amount of space available for a given number of people -- reducing spatial density -or decreasing the number of people in a given space -- reducing social density. When nightclubs and similar establishments restrict the number of patrons that may enter they 
are manipulating social density; when prison administrators build more prisons to alleviate overcrowding they are manipulating spatial density. Generally, high social density is more stressful than high spatial density ${ }^{112}$. For example, dormitory accommodation in residential settings has consistently been associated with higher levels of violence and antisocial behaviour than single-room accommodation ${ }^{113}$. Partitioning dormitories and other open spaces can reduce the negative impact of group size ${ }^{114}$. The sense of crowding can be moderated independently of density by a number of social and architectural features in the environment. Positive mood states and efficient room design can reduce the effects of social density while windows, high ceilings, defined corners and light colours can increase the sense of spaciousness ${ }^{115}$. Accordingly, disorder has been found to be lower in nightclubs that create a relaxing ambience ${ }^{116}$. Macintyre and Homel $^{117}$ found that nightclub violence was also reduced by floor plans that regulated patron flow and minimised unnecessary jostling.

Respecting territory Territoriality is the tendency to lay claim to an area and to defend it against intruders. There are two opposing ways that territorial possession might relate to aggression. First, territorial possession can inhibit aggression. 'Home turf' is a place where people can relax and feel in control over their lives. Altman's ${ }^{118}$ privacy regulation model suggests that people require sanctuaries to which to retreat in order to reduce the stress and overstimulation associated with excessive interpersonal contact. Additionally, well-defined territories can reduce disputes by regulating competition for resources ${ }^{119}$. Territorial concerns are particularly problematic in communal settings where residents are forced to share living space. Giving prisoners a sense of ownership over their living 
quarters not only encourages them to take care of the area (as suggested previously under ‘clarifying responsibility') but also contributes to lower levels of prisoner-prisoner violence $^{120}$. Similarly, O’Neill and Paluck ${ }^{121}$ reported a drop in the level of aggression among institutionalised retarded boys when they were given identifiable territories to call their own.

Second, while territorial possession is associated with positive psychological states, invasion of territory is stressful and can provoke an aggressive response. At a macro level, gang warfare is often caused by aggressive reactions to territorial invasion ${ }^{122}$. Similarly, a high proportion of assaults against prisoner officers occur in the prisoners' living areas ${ }^{123}$ suggesting that prisoners become particularly hostile when they feel that their private domain has been invaded. Officers need to take special precaution when entering prisoners' cells and carry out any necessary searches with some sensitivity to the prisoners territorial concerns.

Controlling environmental irritants Many factors in the environment influence behaviour because of their aversive nature and the threat they pose to human well being. Numerous studies have examined the relationship between atmospheric conditions and crime. Positive correlations between temperature and crime rates (particularly violent crime) have been consistently reported ${ }^{124}$. Goranson and King $^{125}$ also showed that riots were more likely to occur during heat waves. LeBeau ${ }^{126}$ reported a relationship between domestic disputes and the temperature-humidity index. Rotton and Frey ${ }^{127}$ reported a causative association between air pollution levels and violent crime. Laboratory studies 
have also shown that aversive noise intensifies aggression ${ }^{128}$. In a field-observation study, Homel and Clark ${ }^{129}$ found that nightclub violence correlated with a range of aggravating environmental features such as amount of cigarette smoke, lack of ventilation and poor lighting.

Many of the findings on environmental stress have been taken up by architects and, in particular, have been applied to institutional designs. For example, older-style prisons are notorious for being stiflingly hot in summer and freezing cold in winter, being inordinately noisy, and having drab interior decor that produces a visual monotony and stimuli deprivation ${ }^{130}$. More recently constructed prisons have air-conditioning, soundabsorbing surfaces, and more attractive interior designs. The impact of these features on levels of institutional violence is hard to assess since it is generally not possible to isolate them from other institutional variables. In one exception, Atlas ${ }^{131}$ reported evidence that assault rates are lower for air-conditioned areas and areas with easy access to showers than for areas where no relief from high temperatures is provided.

\section{Conclusions}

This paper has presented a classification of techniques for controlling situational precipitators of crime. The intention has been to complement Clarke’s familiar classification of opportunity reduction techniques, not to replace it. According to Wortley's ${ }^{132}$ two-stage model, precipitators of crime and opportunities for crime are linked in a temporal sequence. Behaviour is first initiated before the likely consequences of action are considered. Controlling situational precipitators of crime and reducing 
opportunities for crime can be understood not so much as competing prevention approaches, but as approaches directed at different stages of the person-situation interaction.

As Clarke ${ }^{133}$ acknowledged with respect to his classification, inevitably there is some degree of overlap between categories in the present classification and a potential for debate about the appropriate categorisation of particular interventions. Indeed, there has been some shifting around of techniques as ideas for this classification have evolved. For example, in earlier papers ${ }^{134}$ situationally induced disinhibition (the rationale for 'reducing permissibility') relied heavily on the concept of deindividuation. In the present classification, the social aspects of deindividuation have been emphasised and the technique associated with reducing deindividuation ('reducing anonymity') has been included under 'controlling pressures'. At the same time controlling disinhibition by 'reducing permissibility' now emphasises to a greater extent the role of cognitive processes (moral distortions) ${ }^{135}$. However, an argument could be made that reducing deindividuation also contributes to 'reducing permissibility' by helping to clarify responsibility.

Moreover, while the conceptual distinction between precipitators of crime and opportunities for crime is clear enough, there are several points of overlap between the two classifications as they currently exist, with a number of the techniques suggested in this paper similar to ones already suggested by Clarke. In particular, the rationale for Clarke's new category of 'removing excuses' is essentially the same as the rationale for 
'reducing permissibility', and in fact, the name of one technique -- 'rule setting' -- is identical (although the moral rather than legal basis of rules would seem to be emphasised more strongly in the present classification). Moral distortions are considered precipitators in this paper on the grounds that, as with the other techniques that have been outlined, they are primarily concerned with psychologically preparing the individual to commit crime that they would not have otherwise committed. Resolution of these sorts of overlaps is beyond the scope of the current paper. Clearly, however, further work is required to better integrate the two classifications. 


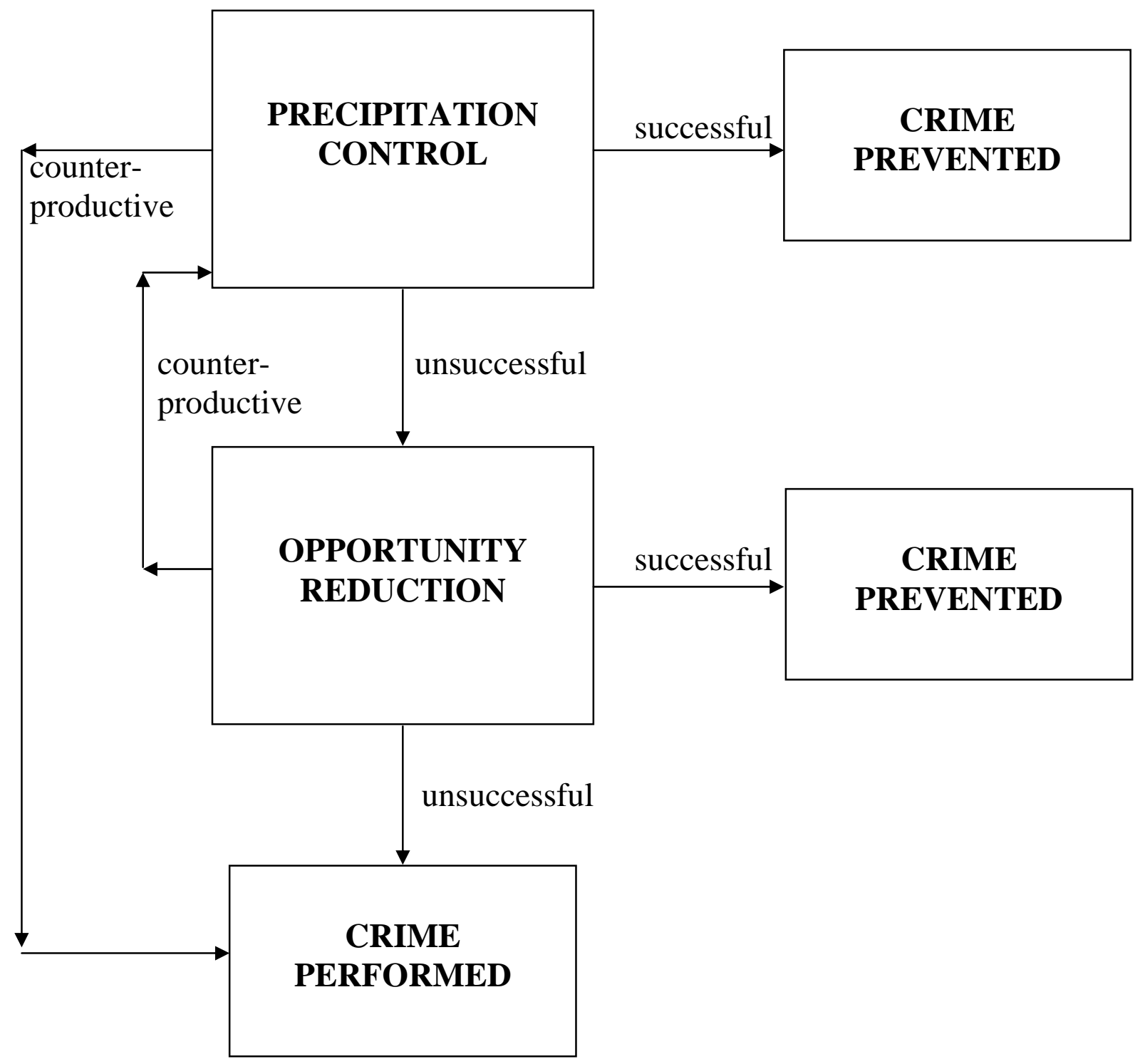

Figure 1 Two stage model of situational crime prevention. 
Table 1 Classification of precipitation-control strategies

\begin{tabular}{|c|c|c|c|}
\hline $\begin{array}{c}\text { Controlling } \\
\text { Prompts }\end{array}$ & $\begin{array}{c}\text { Controlling } \\
\text { Pressures }\end{array}$ & $\begin{array}{c}\text { Reducing } \\
\text { Permissibility }\end{array}$ & $\begin{array}{c}\text { Reducing } \\
\text { Provocations }\end{array}$ \\
\hline $\begin{array}{l}\text { Controlling triggers: } \\
\text { - gun control } \\
\text { - } \text { pornography } \\
\text { restrictions } \\
\text { - environmental } \\
\text { self-management }\end{array}$ & $\begin{array}{l}\text { Reducing } \\
\text { inappropriate } \\
\text { conformity: } \\
\text { - dispersing gang } \\
\text { members } \\
\text { - } \text { screening } \\
\text { children's } \\
\text { associates } \\
\text { - bolstering } \\
\text { independence }\end{array}$ & $\begin{array}{l}\text { Rule setting: } \\
\text { - } \text { harassment codes } \\
\text { - } \text { staff inductions } \\
\text { - 'shoplifting is } \\
\text { stealing' signs }\end{array}$ & $\begin{array}{l}\text { Reducing } \\
\text { frustration: } \\
\text { - inmate control of } \\
\text { comfort settings } \\
\text { - improved wet } \\
\text { playtimes } \\
\text { - efficient road } \\
\text { design }\end{array}$ \\
\hline $\begin{array}{l}\text { Providing } \\
\text { reminders: } \\
\text { - } \text { warning signs } \\
\text { - } \text { symbolic } \\
\text { territorial } \\
\text { markers } \\
\text { - litter bins }\end{array}$ & $\begin{array}{l}\text { Reducing } \\
\text { inappropriate } \\
\text { obedience: } \\
\text { - support for } \\
\text { whistle-blowers } \\
\text { - participatory } \\
\text { management } \\
\text { - semi-independent } \\
\text { units }\end{array}$ & $\begin{array}{l}\text { Clarifying } \\
\text { responsibility: } \\
\text { - } \text { server } \\
\text { intervention } \\
\text { - } \text { assigning } \\
\text { discrete tasks } \\
\text { - encouraging } \\
\text { sense of } \\
\text { ownership }\end{array}$ & $\begin{array}{l}\text { Reducing crowding: } \\
\text { - limiting } \\
\text { nightclub patron } \\
\text { density } \\
\text { - regulating } \\
\text { nightclub patron } \\
\text { flow } \\
\text { - use of colour, } \\
\text { windows, light } \\
\text { etc. }\end{array}$ \\
\hline $\begin{array}{l}\text { Reducing } \\
\text { inappropriate } \\
\text { imitation: } \\
\text { - } \text { rapid repair of } \\
\text { vandalism } \\
\text { - controls on } \\
\text { television content } \\
\text { - supervisors as } \\
\text { exemplars } \\
\end{array}$ & $\begin{array}{l}\text { Encouraging } \\
\text { compliance: } \\
\text { - } \text { persuasive signs } \\
\text { - fairness of } \\
\text { request } \\
\text { - participation in } \\
\text { rule-making }\end{array}$ & $\begin{array}{l}\text { Clarifying } \\
\text { consequences: } \\
\text { - } \text { copyright } \\
\text { messages } \\
\text { - public posting } \\
\text { - vandalism } \\
\text { information } \\
\text { brochures }\end{array}$ & $\begin{array}{l}\text { Respecting territory: } \\
\text { - } \text { identifiable } \\
\text { territories for } \\
\text { residents } \\
\text { - privacy rooms } \\
\text { for residents } \\
\text { - avoiding } \\
\text { intrusions into } \\
\text { inmates' cells } \\
\end{array}$ \\
\hline $\begin{array}{l}\text { Setting positive } \\
\text { expectations: } \\
\text { - pub } \\
\text { gentrification } \\
\text { - domestic prison } \\
\text { furniture } \\
\text { - fixing 'broken } \\
\text { windows' }\end{array}$ & $\begin{array}{l}\text { Reducing } \\
\text { Anonymity: } \\
\text { - } \quad \text { restricting } \\
\text { uniform use } \\
\text { (perpetrators) } \\
\text { - } \text { school dress } \\
\text { codes } \\
\text { - low-profile } \\
\text { crowd } \\
\text { management }\end{array}$ & $\begin{array}{l}\text { Personalising } \\
\text { victims: } \\
\text { - victim co- } \\
\text { operation } \\
\text { - humanising } \\
\text { conditions for } \\
\text { prisoners } \\
\text { - concern with } \\
\text { employee welfare }\end{array}$ & $\begin{array}{l}\text { Controlling } \\
\text { environmental } \\
\text { irritants: } \\
\text { - } \quad \text { smoke-free } \\
\text { nightclubs } \\
\text { - } \text { air conditioning } \\
\text { - noise control }\end{array}$ \\
\hline
\end{tabular}




\section{Notes}

${ }^{1}$ School of Criminology and Criminal Justice, Griffith University, Brisbane 4111, Australia. E-mail R.Wortley@mailbox.gu.edu.au. The author wishes to thank Ron Clarke for his helpful comments on earlier drafts of this article.

${ }^{2}$ Clarke, R.V. (1992) Introduction. In Clarke, R.V (ed) Situational Crime Prevention: Successful Case Studies. Albany, NY: Harrow and Heston; Clarke, R.V. (1997) Introduction. In Clarke, R.V. (ed) Situational Crime Prevention: Successful Case Studies, $2^{\text {nd }}$ edition. Albany, NY: Harrow and Heston.

${ }^{3}$ Ibid.

${ }^{4}$ Clarke (1997), ibid; Clarke, R.V. and Homel, R. (1997) A Revised Classification of Situational Crime Prevention Techniques. In Lab, S.P (ed) Crime Prevention at the Crossroads. Cincinnati, OH: Anderson.

${ }^{5}$ Cornish, D.B. and Clarke, R.V. (1986), The Reasoning Criminal. Rational Choice Perspectives on Offending. New York, NY: Springer-Verlag.

${ }^{6}$ Wortley, R. (1997) Reconsidering the Role of Opportunity in Situational Crime Prevention. In Newman, G., Clarke, R.V. and Shohan, S.G. (eds) Rational Choice and 
Situational Crime Prevention. Aldershot: Ashgate Publishing; Wortley, R. (1998) A Two-Stage Model of Situational Crime Prevention. Studies on Crime and Crime Prevention. Vol. 7 No. 2, pp 173-188; Wortley, R. (in press). Situational Prison Control: Crime Prevention in Correctional Institutions. Cambridge: Cambridge University Press.

${ }^{7}$ Wortley (1998), ibid.

${ }^{8}$ Wortley, R. (1996) Guilt, Shame and Situational Crime Prevention. In Homel, R. (ed) The Politics and Practice of Situational Crime Prevention. Crime Prevention Studies Vol. 5. Monsey, NY: Criminal Justice Press. Wortley (1998), ibid; Wortley (1997), op cit; Wortley (in press), op cit.

${ }^{9}$ Wortley (1998), ibid; Wortley (1997), op cit; Wortley (in press), op cit.

${ }^{10}$ Berkowitz, L. (1983) The Experience of Anger as a Parallel Process in the Display of Impulsive, ‘Angry’ Aggression. In Green, R.G. and Donnerstein, E.I. (eds) Aggression: Theoretical and Empirical Reviews, Vol. 1. New York, NY: Academic Press.

${ }^{11}$ Veno, A. and Davidson, M. (1977) Prison Violence: Some Different Perspectives. International Journal of Criminology and Penology. Vol. 5 No. 4, pp 399-409.

${ }^{12}$ Goldstein, M., Kant, H.S. and Hartman, J.J. (1974) Pornography and Sexual Deviance. Berkeley: University of California Press. 
${ }^{13}$ Marshall, W.L. (1988) The Use of Explicit Sexual Stimuli by Rapists, Child Molestors and Nonoffender Males. Journal of Sex Research. Vol. 25 No. 2, pp 267-288.

${ }^{14}$ Schneider, H.J. (1996) Violence in the Mass Media. Studies on Crime and Crime Prevention. Vol. 5 No. 1, pp 59-71.

${ }^{15}$ Barbaree, H.E. and Marshall, W.L. (1989) Erectile Responses Amongst Heterosexual Child Molestors, Father-daughter Incest Offenders, and Matched Nonoffenders: Five Distinct Age Preference Profiles. Canadian Journal of Behavioral Science. Vol. 21 No. 1, pp 70-82.

${ }^{16}$ Gillies, L.A., Hashmall, J.M., Hilton, N.Z. and Webster, C.D. (1992) Relapse Prevention in Pedophiles: Clinical Issues and Program Development. Canadian Psychology. Vol. 33 No. 2, pp 199-210.

${ }^{17}$ Marlatt, G.A. (1996) Taxonomy of High-Risk Situations for Alcohol Relapse: Evolution and Development of a Cognitive-Behavioral Model. Addictions. Vol. 91 (Supplement), pp S37-S49.

${ }^{18}$ Geller, E.S., Witmer, J.F. and Tuso, M.A. (1977) Environmental Interventions for Litter Control. Journal of Applied Psychology. Vol. 62 No. 3, pp 344-351. 
${ }^{19}$ Weinstein, N.D., Grubb, P.D. and Vautier, J.S. (1986) Increasing Automobile Seat Belt Use: An Intervention Emphasizing Risk Susceptibility. Journal of Applied Psychology. Vol. 71 No. 2, pp 285-290.

${ }^{20}$ Cope, J.G. and Allred, L.J. (1991) Community Intervention to Deter Illegal Parking in Spaces Reserved for the Physically Disabled. Journal of Applied Behavioral Analysis. Vol. 24 No. 4, pp 687-693; Cope, J.G., Lanier, T.M. and Allred, L.J. (1995) Controlling Illegal Parking in Spaces Reserved for the Physically Disabled. Environment and Behavior. Vol. 27 No. 3, pp 317-327.

${ }^{21}$ Watson, T.S. (1996) A Prompt Plus Delayed Contingency Procedure for Reducing Bathroom Graffiti. Journal of Applied Behavioral Analysis. Vol. 29 No. 1, pp 121-124.

${ }^{22}$ Durdan, C.A., Reeder, G.D. and Hecht, P.R. (1985) Litter in a University Cafeteria: Demographic Data and the Use of Prompts as an Intervention Strategy. Environment and Behavior. Vol. 17 No. 3, pp 387-404; Marler, L. (1971) A Study of Anti-littering Messages. Journal of Environmental Education. Vol. 3 No. 1, pp 52-53; Reiter, S.M. and Samuel, W. (1980) Littering as a Function of Prior Litter and the Presence or Absence of Prohibitive Signs. Journal of Applied Social Psychology. Vol. 10 No. 1, pp 45-55.

${ }^{23}$ Geller, E.S., Witmer, J.F. and Orebaugh, A.L. (1976) Instructions as a Determinant of Paper-Disposal Behaviors. Environment and Behavior. Vol. 8 No. 3, pp 417-439. 
${ }^{24}$ Harrell, W.A. (1992) Driver Response to a Disabled Pedestrian Using a Dangerous Crosswalk. Journal of Environmental Psychology. Vol. 12 No. 4, pp 345-354.

${ }^{25}$ Brothers, K.J., Krantz, P.J. and McClannahan, L.E. (1994) Office Paper Recycling: A Function of Container Proximity. Journal of Applied Behavioral Analysis. Vol. 27 No. 1, pp 153-160; Cope, J.G., Huffman, K.T., Allred, L.J. and Grossnickle, W.F. (1993) Behavioral Strategies to Reduce Cigarette Litter. Journal of Social Behavior and Personality. Vol. 8 No. 4, pp 607-619; Durdan et al, op cit; Finnie, W.C. (1973) Field Experiments in Litter Control. Environment and Behavior. Vol. 5 No. 2, pp 123-144.

${ }^{26}$ Cope et al (1993), ibid; Geller, E.S., Brasted, W. and Mann, M. (1980) Waste Receptacles Designs as Interventions for Litter Control. Journal of Environmental Systems. Vol. 9 No. 2, pp 145-160.

${ }^{27}$ Newman, O. (1972) Defensible Space: People and Design in the Violent City. London: Architectural Press.

${ }^{28}$ Brown, B.B. and Altman, I. (1983) Territoriality, Defensible Space and Residential Burglary: An Environmental Analysis. Journal of Environmental Psychology. Vol. 3 No. 3, pp 203-220. 
${ }^{29}$ Bandura, A. (1965) Influence of Models’ Reinforcement Contingencies on the Acquisition of Imitative Responses. Journal of Personality and Social Psychology. Vol. 1 No. 6, pp 589-95.

${ }^{30}$ Lefkowitz, M., Blake, R.R. and Mouton, J.S. (1955) Status Factors in Pedestrian Violation of Traffic Signals. Journal of Abnormal and Social Psychology. Vol. 51, pp 704-705.

${ }^{31}$ Skinner, W.F. and Fream, A.M. (1997) A Social Learning Theory Analysis of Computer Crime Among College Students. Journal of Research in Crime and Delinquency. Vol. 34 No. 4, pp 495-518.

${ }^{32}$ Adams, V. (1981) How to Keep 'em Honest: Honesty as an Organisational Policy Can Help Prevent Employee Theft. Psychology Today. Vol. 15 No. 11 November, pp 50, 53; Cherrington, D.J. and Cherrington, J.O. (1985) The Climate of Honesty in Retail Stores. In Terris, W. (ed) Employee Theft: Research, Theory, and Applications. Park Ridge, IL: London House; Hollinger, R.C. (1989) Dishonesty in the Workplace: A Manager's Guide to Preventing Employee Theft. Park Ridge, IL: London House; Snyder, N.H., Broome, O.W., Kehoe, W.J., McIntyre, J.T. and Blair, K.E. (1991) Reducing Employee Theft: A guide to Financial and Organisational Controls. New York: Quorum.

${ }^{33}$ Gould, M.S. and Shaffer, D. (1989) The Impact of Suicide in Television Movies. Evidence of Imitation. In Diekstra, R.F.W., Maris, R., Platt, S., Schmidtke, A. and 
Sonneck, G. (eds) Suicide and its Prevention. New York: E. J. Brill; Phillips, D.P. (1989) Recent Advances in Suicidology. The Study of Imitative Suicide. In Diekstra, R.F.W., Maris, R., Platt, S., Schmidtke, A. and Sonneck, G. (eds) Suicide and its Prevention. New York: E. J. Brill; Phillips, D.P. and Carstensen, L.L. (1990) The Effects of Suicide Stories on Various Demographic Groups 1968-1985. In Surette, R. (ed) The Media and Criminal Justice Policy. Springfield, Il: Charles C Thomas; Schmidtke, A. and Häfner, H. (1989) Public Attitudes Towards and Effects of the Massmedia on Suicidal and Deliberative Self-harm Behavior. In Diekstra, R.F.W., Maris, R., Platt, S., Schmidtke, A. and Sonneck, G. (eds) Suicide and its Prevention. New York: E. J. Brill.

${ }^{34}$ Leyens, J.P., Camino, L., Parke, R.D. and Berkowitz, L. (1975) Effects of Movie Violence on Aggression in a Field Setting as a Function of Group Dominance and Cohesion. Journal of Personality and Social Psychology. Vol. 32 No. 2, pp 346-360; Rosenthal, R. (1990) Media Violence, Antisocial Behavior, and the Social Consequences of Small Effects. In Surette, R. (ed) The Media and Criminal Justice Policy. Springfield, Il: Charles C Thomas.

${ }^{35}$ Phillips, D.P. (1983) The Impact of Mass Media Violence on U.S. Homicides. American Sociological Review. Vol. 48 No. 4, pp 560-568.

${ }^{36}$ Surette, R. (1990) Estimating the Magnitude and Mechanisms of Copycat Crime. In Surette, R. (ed) The Media and Criminal Justice Policy. Springfield, Il: Charles C Thomas. 
${ }^{37}$ Roggenbuck, J.W. and Passineau, J. (1986) Use of the Field Experiment to Assess the Effectiveness of Interpretation. In McDonald B. and Cordell, H.K. (eds) Proceedings, Southeastern Recreation Research Conference. Athens, GA: University of Georgia.

${ }^{38}$ Boye, M.W. and Jones, J.W. (1997) Organizational Culture and Employee Counterproductivity. In Giacalone, R.A. and Greenberg, J. (eds) Antisocial Behavior in Organisations. Thousand Oaks, CA: Sage; Greenberg, J. (1997) The STEAL Motive. Managing the Social Determinants of Employee Theft. In Giacalone, R.A. and Greenberg, J. (eds) Antisocial Behavior in Organisations. Thousand Oaks, CA: Sage.

${ }^{39}$ Phillips and Carstensen, op cit; Surette, op cit.

${ }^{40}$ Sloan-Howitt, M. and Kelling, G.L. (1997) Subway Graffiti in New York City: 'Gettin Up' vs. 'Meanin it and Cleanin it'. In: Clarke, R.V. (ed) Situational Crime Prevention: Successful Case Studies, $2^{\text {nd }}$ ed. Albany, NY: Harrow and Heston.

${ }^{41}$ Challinger, D. (1992) Less Telephone Vandalism: How Did it Happen? In Clarke, R.V. (ed) Situational Crime Prevention: Successful Case Studies. Albany, NY: Harrow and Heston; Samdahl, D.M. and Christensen, H.H. (1985) Environmental Cues and Vandalism: An Exploratory Study of Picnic Table Carving. Environment and Behavior. Vol. 17 No. 4, pp 445-458. 
${ }^{42}$ Geller et al (1977), op cit; Herberlein, T.A. (1971) Moral Norms, Threatened Sanctions and Littering Behavior. Unpublished PhD Dissertation, University of Wisconsin.

${ }^{43}$ Graham, K. and Homel, R. (1996) Creating Safer Bars. In Plant, M., Single, E. and Stockwell, T. (eds) Alcohol: Minimising the Harm. London: Free Association Press.

${ }^{44}$ Atlas, R.I. and Dunham, R.G. (1990) Changes in Prison Facilities as a Function of Correctional Philosophy. In Murphy, J.W. and Dison, J.E. (eds) Are Prisons Any Better? Twenty Years of Correctional Reform. Newbury Park, CA: Sage; Zupan, L.L. (1991) Jails: Reform and the New Generation Philosophy. Cincinnati, OH: Anderson Publishing.

${ }^{45}$ Wilson, J.Q. and Kelling, G. (1982) The Police and Neighborhood Safety: Broken Windows. The Atlantic Monthly. Vol. 249 No. 3 March, pp 29-38.

${ }^{46}$ Howard, J.L. (1978) Factors in School Vandalism. Journal of Research and Development in Education. Vol. 11 No. 2, pp 53-63; Perkins, D.D., Wandersman, A., Rich, R.C. and Taylor, R.B. (1993) The Physical Environment of Street Crime: Defensible Space, Territoriality and Incivilities. Journal of Environmental Psychology. Vol. 13 No. 1, pp 29-49.

${ }^{47}$ Akers, R.L., Krohn, M.D., Lanza-Kaduce, L. and Radosevich, M. (1979) Social Learning and Deviant Behavior: A Specific Test of a General Theory. American 
Sociological Review. Vol. 44 No. 4, pp 636-655; Jensen, G.F. (1972) Parents, Peers, and Delinquent Action. American Journal of Sociology. Vol. 78 No. 3, pp 562-575; Warr, M. and Stafford, M. (1991) The Influence of Delinquent Peers: What They Think or What They Do? Criminology. Vol. 29 No. 4. pp 851-865.

${ }^{48}$ Le Blanc, M. (1995) Common, Temporary and Chronic Delinquency. Prevention Strategies During Compulsory School. In Wikstrom, P.H., Clarke, R.V. and McCord, J. (eds) Integrating Crime Prevention Strategies: Propensity and Opportunity. Stockholm: National Council for Crime Prevention.

${ }^{49}$ Kallis, M.J. and Vanier, D.J. (1985) Consumer Shoplifting: Orientations and Deterrents. Journal of Criminal Justice. Vol. 13 No. 5, pp 470.

${ }^{50}$ Dale, R.R. (1991) Mixed Versus Single Sex Schools: The Social Aspects of Bullying. In Elliot, M. (ed) Bullying: A Practical Guide to Coping for Schools. Harlow: Longman.

${ }^{51}$ Hawkins, J.D. and Lishner, D.M. (1987) Schooling and Delinquency. In: Johnson, E.H. (ed) Handbook on Crime and Delinquency Prevention. New York: Greenwood Press.

${ }^{52}$ Altheide, K.K., Adler, P.A., Adler, P. and Altheide, D.A. (1978) The Social Meaning of Employee Theft. In Johnson J.M. and Douglas, J.D. (eds) Crime at the Top: Deviance in Business and the Professions. Philadelphia, PA: J. B. Lippincott; Clark, J.B. and Hollinger, R.C. (1983) Theft by Employees in Work Organizations. Washington, DC: 
U.S. Department of Justice; Horning, D.N.M. (1970) Blue-Collar Theft: Conceptions of Property, Attitudes Towards Pilfering, and Work Group Norms in a Modern Industrial Plant. In Smigel E.O. and Ross, H.L. (eds) Crimes Against Bureaucracy. New York: Van Nostrand Reinhold; Jaspan, N. (1974) Mind Your Own Business. Englewood Cliffs, NJ: Prentice Hall.

${ }^{53}$ Greenberg, op cit.

${ }^{54}$ Addis, K.K. (1992) Company Crooks on the Line. Security Management. Vol 36 July, pp 36, 38, 40, 42.

${ }^{55}$ Mabli, J., Holley, C., Patrick, J. and Walls, J. (1979) Age and Prison Violence. Criminal Justice and Behavior. Vol. 6 No. 2, pp 175-185.

${ }^{56}$ Smykla, J.O. (ed) (1980) Coed Prison. New York: Human Sciences Press.

${ }^{57}$ Ralph, P.H. and Marquart, J.W. (1993) Gang Violence in Texas Prisons. Prison Journal. Vol. 71, No. 2, pp 38-49.

${ }^{58}$ Milgram, S. (1974) Obedience to Authority: An Experimental View. New York: Harper and Row. 
${ }^{59}$ Kelman, H.C. and Hamilton, V.L. (1989) Crimes of Obedience. Binghamton, NY: Yale University Press.

${ }^{60}$ Ibid.

${ }^{61}$ Ibid.

${ }^{62}$ Fitzgerald, G. (1989) Commission of Inquiry into Possible Illegal Activities and Associated Police Misconduct. Brisbane: Queensland Government Printer.

${ }^{63}$ Nagle, J.F. (1978) Report of the Royal Commission into New South Wales Prisons. Sydney: NSW Government Printer.

${ }^{64}$ Kelman and Hamilton, op cit.

${ }^{65}$ see also Metzger, M.B. and Schwenk, C.R. (1990) Decision Making Models, Devil's Advocacy, and the Control of Corporate Crime. American Business Law Journal. Vol. 28 Fall, pp 323-377.

${ }^{66}$ Durdan et al, op cit; Geller, E.S., Koltuniak, T.A. and Shilling, J.S. (1983) Response Avoiding Prompting: A Cost-effective Strategy for Theft Deterrence. Behavioral Counseling and Community Interventions. Vol. 3 No. 1, pp 28-42; Reich, J.W. and 
Robertson, J.L. (1979) Reactance and Norm Appeal in Anti-littering Messages. Journal of Applied Social Psychology. Vol. 9 No. 1, pp 91-101; Reiter and Samuel, op cit.

${ }^{67}$ Ibid.

${ }^{68}$ Snyder et al, op cit.

${ }^{69}$ in Roggenbuck, J.W. (1992) Use of Persuasion to Reduce Resources Impacts and Visitor Conflicts. In Manfredo, M.J (ed) Influencing Human Behavior: Theory and Applications in Recreation, Tourism, and Natural Resources Management. Champaign, IL: Sagamore.

${ }^{70}$ Oliver, S.S., Roggenbuck, J.W. and Watson, A.E. (1985) Education to Reduce Impacts in Forest Campgrounds. Journal of Forestry. vol. 83 No. 4, pp 234-236.

${ }^{71}$ Bensley, L.S. and Wu, R. (1991) The Role of Psychological Reactance in Drinking Following Alcohol Prevention Messages. Journal of Applied Social Psychology. Vol. 21 No. 13, pp 1111-1124.

${ }^{72}$ Bushman, B.J. and Stack, A.D. (1996) Forbidden Fruit Versus Tainted Fruit: Effects of Warning Labels on Attraction to Television Violence. Journal of Experimental Psychology: Applied. Vol. 2 No. 3, pp 207-226. 
${ }^{73}$ Kauffman, K. (1988) Prison Officers and Their World. Cambridge, MA: Harvard University Press; Lombardo, L.X. (1989) Guards Imprisoned: Correctional Officers at Work 2nd ed. Cincinnati OH: Anderson.

${ }^{74}$ Bottoms, A.E., Hay, W. and Sparks, J.R. (1995) Situational and Social Approaches to the Prevention of Disorder in Long-term Prisons. In Flanagan, T.J. (ed) Long-term Imprisonment. Thousand Oaks, CA: Sage; Lombardo (1989), ibid; Sparks, R., Bottoms, A. and Hay, W. (1996) Prison and the Problem of Order. Oxford: Clarendon.

${ }^{75}$ Haney, C., Banks, C. and Zimbardo, P. (1973) Interpersonal Dynamics in a Simulated Prison. International Journal of Criminology and Penology. Vol. 1 No. 1, pp 69-97.

${ }^{76}$ McKenzie, I.K. (1982) Unlawful Assembly: Riot, Rout: The Mechanisms of the Mob. Police Studies. Vol. 5 No. 1, pp 40-46.

${ }^{77}$ Veno, A. and Veno, E. (1993) Situational Prevention of Public Disorder at the Australian Motorcycle Grand Prix. In Clarke, R.V. (ed) Crime Prevention Studies Vol 1. Monsey, NY: Criminal Justice Press.

${ }^{78}$ Reicher, S. (1991) Politics of Crowd Psychology. The Psychologist. Vol. 4 No. 12 Nov, pp 487-91; Scarman, Lord. (1981) The Brixton Disorders: 10-12 April, 1981. Report of the Inquiry. London: Her Majesty’s Stationery Office; Shellow, R. and 
Roemer, D.V. (1987) No Heaven for ‘Hell’s Angels’. In Turner R.H. and Killian, L.M.

(eds) Collective Behavior, $3^{\text {rd }}$ ed. Englewood Cliffs, NJ: Prentice-Hall.

${ }^{79}$ Sykes, G. and Matza, D. (1957) Techniques of Neutralization: A Theory of

Delinquency. American Sociological Review. Vol. 22 Dec, pp 664-670.

${ }^{80}$ Bandura, A. (1977) Social Learning Theory. Englewood Cliffs, NJ: Prentice-Hall; Wortley (1996), op cit.

${ }^{81}$ Clark and Hollinger, op cit; Greenberg, op cit.

${ }^{82}$ Parilla, P.F., Hollinger, R.C. and Clark, J.P. (1988) Organizational Control of Deviant Behavior: The Case of Employee Theft. Social Science Quarterly. Vol. 69 No. 2, pp 261280.

${ }^{83}$ Elliot, M., (ed) (1991), Bullying: A Practical Guide to Coping for Schools. Harlow: Longman.

${ }^{84}$ Randall, P. (1997) Adult Bullying. London: Routledge.

${ }^{85}$ Clarke and Homel, op cit. 
${ }^{86}$ Lang, A.R., Goeckner, D.J., Adesso, V.G. and Marlatt, G.A. (1975) Effects of Alcohol on Aggression in Male Social Drinkers. Journal of Abnormal Psychology. Vol. 84 No. 5, pp 508-518; Sobell, M.B. and Sobell, L.C. (1973) Individualized Behavior Therapy for Alcoholics. Behavior Therapy. Vol. 4 No. 1, pp 49-72.

${ }^{87}$ Homel, R., Hauritz, M., Wortley, R., McIlwain, G. and Carvolth, R. (1997) Preventing Alcohol-related Crime Through Community Action: The Surfers Paradise Safety Action Project. In Homel, R. (ed) Policing for Prevention. Crime Prevention Studies, Vol. 7. Monsey, NY: Criminal Justice Press.

${ }^{88}$ Clarke and Homel, op cit.

${ }^{89}$ Bandura, op cit.

${ }^{90}$ Foster, J. and Hope, T. (1993) Housing, Community and Crime: The Impact of the Priority Estates Project. Home Office Research Study No. 131. London: H. M. Stationery Office; Power, A. (1994) Local Housing Management, London: Department of Environment.

${ }^{91}$ Wener, R. and Olsen, R. (1980) Innovative Correctional Environments: A User Assessment. Environment and Behavior. Vol. 12 No. 4, pp 478-493; Zupan, op cit.

${ }^{92}$ Greenberg, op cit. 
${ }^{93}$ Carter, N., Holström, A., Simpanen, M. and Melin, K. (1988) Theft Reduction in a Grocery Store Through Product Identification and Graphing of Losses for Employees. Journal of Applied Behavioral Analysis. Vol. 21 No. 4, pp 385-389.

${ }^{94}$ Oliver et al (1985), op cit.

${ }^{95}$ Vander Stoep, G. and Gramann, J. (1987) The Effect of Verbal Appeals and Incentives on Depreciative Behavior Among Youthful Park Visitors. Journal of Leisure Research. Vol. 19 No. 2, pp 69-83.

${ }^{96}$ Silbert, M.H. and Pines, A.M. (1984) Pornography and Sexual Abuse of Women. Sex Roles. Vol. 10, pp 857-868.

${ }^{97}$ Indermaur, D. (1996) Reducing Opportunities for Violence in Robbery and Property Crime: The Perspectives of Offenders and Victims. In Homel, R. (ed) The Politics and Practice of Situational Crime Prevention. Crime Prevention Studies, Vol. 5. Monsey, NY: Criminal Justice Press.

${ }^{98}$ Olweus, D. (1978) Aggression in Schools. Washington DC: Hemisphere.

${ }^{99}$ Besag, V.E. (1989) Bullies and Victims in Schools. Milton Keynes: Open University Press. 
${ }^{100}$ Hollinger, R.C., Slora, K.B. and Terris, W. (1992) Deviance in the Fast-food Restaurant: Correlates of Employee Theft, Altruism, and Counterproductivity. Deviant Behavior. Vol. 13 No. 2, pp 155-184; Hollinger, R.C. and Clark, J.P. (1983) Theft by Employees. Lexington, MA: Lexington Books; Jones, J.W. (1981) Attitudinal Correlates of Employee Theft of Drugs and Hospital Supplies Among Nursing Personnel. Journal of Nursing Research. Vol. 30 No. 6, pp 349-351; Kamp, J. and Brooks, P. (1991) Perceived Organizational Climate and Employee Counterproductivity. Journal of Business and Psychology. Vol. 5 No. 4, pp 447-458.

${ }^{101}$ Greenberg, J. (1990) Employee Theft as a Reaction to Underpayment Inequity: The Hidden Cost of Pay Cuts. Journal of Applied Psychology. Vol. 75 No. 6, pp 561-568.

${ }^{102}$ Boye and Jones, op cit; Johnson, E. H. (1987) Prevention in Business and Industry. In Johnson, E.H. (ed) Handbook on Crime and Delinquency Prevention. New York: Greenwood Press.

${ }^{103}$ Harding, R.W., Morgan, F.H., Indermaur, D., Ferrante, A.M. and Blagg, H. (1998) Road Rage and the Epidemiology of Violence: Something Old, Something New. Studies on Crime and Crime Prevention. Vol. 7 No. 2, pp 221-238.

${ }^{104}$ Chen, P.Y. and Spector, P.E. (1992) Relationship of Work Stressors with Aggression, Withdrawal, Theft and Substance Use: An Exploratory Study. Journal of Occupational 
and Organizational Psychology. Vol. 65 No. 3, pp 177-184; Spector, P.E. (1997) The Role of Frustration in Antisocial Behavior at Work. In Giacalone, R.A. and Greenberg, J. (eds) Antisocial Behavior in Organisations. Thousand Oaks, CA: Sage; Storms, P.L. and Spector, P.E. (1987) Relationships and Organizational Frustration with Reported Behavioral Reactions: The Moderating Effect of Perceived Control. Journal of Occupational Psychology. Vol. 60 No. 3, pp 227-234.

${ }^{105}$ Homel, R. and Clark, J. (1994) The Prediction and Prevention of Violence in Pubs and Clubs. In Clarke, R.V. (ed) Crime Prevention Studies, Vol. 3. Monsey, NY: Criminal Justice Press.

${ }^{106}$ Boulton, M.J. (1994) Understanding and Preventing Bullying in the Junior School Playground. In Smith, P.K. and Sharp, S. (eds) School Bullying. London: Routledge.

${ }^{107}$ Wener and Olsen (1978), op cit.

${ }^{108}$ Baum, A. and Valins, S. (1977) Architecture and Social Behavior: Psychological Studies of Social Density. Hillsdale NJ: Erlbaum.

${ }^{109}$ Homel and Clark, op cit; Macintyre, S. and Homel, R. (1997) Danger on the dance floor. A study on interior design, crowding and aggression in nightclubs. In Homel R. (ed.) Policing for Prevention: Reducing Crime, Public Intoxication and Injury. Crime Prevention Studies, Vol. 7. Monsey NY, Criminal Justice Press. 
${ }^{110}$ Dean, L.M., Pugh, W.M. and Gunderson, E.K. (1978) The Behavioral Effects of Crowding: Definitions and Methods. Environment and Behavior. Vol. 10 No. 3, pp 41331.

${ }^{111}$ Cox, V.C., Paulus, P.B. and McCain, G. (1984) Prison Crowding Research: The Relevance for Prison Housing Standards and a General Approach Regarding Crowding Phenomena. American Psychologist. Vol. 39 Vol 10, pp 1148-1160; Gaes, G.G. and McGuire, W.J. (1985) Prison Violence: The Contribution of Crowding Versus Other Determinants of Prison Assault Rates. Journal of Research in Crime and Delinquency. Vol. 22 No. 1, pp 41-65; Paulus, P. (1988) Prison Crowding: A Psychological Perspective. New York, NY: Springer-Verlag.

${ }^{112}$ Baum and Vallins, op cit; Cox et al, op cit; Paulus, op cit.

${ }^{113}$ Atlas, R. (1982) Violence in Prison: Architectural Determinism. Unpublished doctoral thesis, School of Criminology, Florida State University; Cox et al (1984), ibid; O’Donnell, I. and Edgar, K. (1996) The Extent and Dynamics of Victimisation in Prisons. Oxford: Centre for Criminological Research, University of Oxford; Sylvester, S.F., Reed, J.H. and Nelson, D.O. (1977) Prison Homicide. New York: Spectrum.

${ }^{114}$ Baum, A., Riess, M. and O’Hara, J. (1974) Architectural Variants of Reaction to Spatial Invasion. Environment and Behavior. Vol. 6 No. 1, pp 91-100; McCain, G., Cox, 
V. and Paulus, P.B. (1980) The Effect of Prison Crowding on Inmate Behavior.

Washington DC: Law Enforcement Assistance Administration.

${ }^{115}$ Desor, J.A. (1972) Toward a Psychological Theory of Crowding. Journal of Personality and Social Psychology. Vol. 21 No. 1, pp 79-83; Marrero, D. (1977) Spatial Dimensions of Democratic Prison Reform. Prison Journal. Vol. 57, No. 2, pp 31-42; Nacci, P.L., Teitelbaum, H.E. and Prather, J. (1977) Population Density and Inmate Misconduct Rates in the Federal Prison System. Federal Probation. Vol. 41 No. 2, pp 2631; Paulus, P.B. and Nagar, D. (1989) Environmental Influences on Groups. In Paulus, P.B (ed) Psychology of Group Influence, $2^{\text {nd }}$ ed. Hillsdale, NJ: Lawrence Erlbaum; Savinar, J. (1975) The Effect of Ceiling Height on Personal Space. Man-Environment Systems. Vol. 5 No. 5, pp 321-324.

${ }^{116}$ Homel and Clark, op cit.

${ }^{117}$ Macintyre and Homel, op cit.

${ }^{118}$ Altman, I. (1975) The Environment and Social Behavior. Monterey, CA: Brooks/Cole.

${ }^{119}$ Ley, D. and Cybriwsky, R. (1974) Urban Graffiti as Territorial Markers. Annals of the Association of American Geographers. Vol. 64 No. 4, pp 491-505. 
${ }^{120}$ Bayens, G.J., Williams, J.J. and Smykla, J.O. (1997) Jail Type and Inmate Behavior: A Longitudinal Analysis. Federal Probation. Vol 61 No. 3, pp 54-62; Farbstein, J. and Wener, R. (1989) A Comparison of 'Direct' and 'Indirect' Supervision Correctional Facilities. Final Report. Washington DC: National Institute of Corrections, Prison Division, U.S. Department of Justice; Sigurdson, H.R. (1985) The Manhattan House of Detention: A Study of Podular Direct Supervision. National Institute of Corrections, U.S. Department of Justice; Wener, R., Frazier, W. and Farbstein, J. (1987) Building Better Jails. Psychology Today. Vol. 21, No. 6, pp 40-49.

${ }^{121}$ O’Neill, S.M. and Paluck, B.J. (1973) Altering Territoriality Through Reinforcement. Proceedings of the 81st Annual Convention of the American Psychological Association. Montreal, Canada.

${ }^{122}$ Ley and Cybriwsky, op cit.

${ }^{123}$ Atlas (1982), op cit; Atlas, R. (1983) Crime Site Selection for Assaults in Four Florida Prisons. Prison Journal. Vol. 58 No. 1, pp 59-72; Light, S.C. (1991) Assaults on Prison Officers: Interactional Themes. Justice Quarterly. Vol. 8 No. 2, pp 241-261; Sylvester et al, op cit.

${ }^{124}$ Anderson, C.A. (1987) Temperature and Aggression: Effects on Quarterly, Yearly and City Rates of Violent and Non-Violent Crime. Journal of Personality and Social Psychology. Vol. 52 No. 6, pp 1161-1173; Anderson, C.A., Bushman, B.J. and Groom, 
R.W. (1997) Hot Years and Serious Deadly Assault: Empirical Test of the Heat Hypothesis. Journal of Personality and Social Psychology. Vol. 73 No. 6, pp. 1213-1223; Cohn, E.G. and Rotton, J. (1997) Assault as a Function of Time and Temperature: A Moderator-variable Time-series Analysis. Journal of Personality and Social Psychology. Vol. 72 No. 6, pp 1322-1334; Cotton, J.L. (1986) Ambient Temperature and Violent Crime. Journal of Applied Social Psychology. Vol. 16 No. 9, pp 786-801; Field, S. (1992) The Effect of Temperature on Crime. British Journal of Criminology. Vol. 32 No. 3, pp 340-351; Harries, K.D. and Stadler, S.J. (1988) Heat and Violence: New Findings From the Dallas Field Data, 1980-1981. Journal of Applied Social Psychology. Vol. 18 No. 2, pp 129-38.

${ }^{125}$ Goranson, R.E. and King, D. (1970) Rioting and Daily Temperature: Analysis of the U.S. Riots in 1967. Toronto: York University.

${ }^{126}$ LeBeau, J.L. (1994) The Oscillation of Police Calls to Domestic Disputes with Time and the Temperature Humidity Index. Journal of Crime and Justice. Vol. 17 No. 1, pp 149-161.

${ }^{127}$ Rotton, J. and Frey, J. (1985) Air Pollution, Weather, and Violent Crimes: Concomitant Time-series Analysis of Archival Data. Journal of Personality and Social Psychology. Vol. 49 No. 5, pp 1207-1220. 
${ }^{128}$ Donnerstein, E. and Wilson, D.W. (1976) Effects of Noise and Perceived Control on Ongoing and Subsequent Aggressive Behavior. Journal of Personality and Social Psychology. Vol. 34 No. 5, pp 774-781; Konecni, V.J., Libuser, L., Morton, H. and Ebbersen, E.B. (1975) Effects of a Violation of Personal Space on Escape and Helping Responses. Journal of Experimental Social Psychology. Vol. 11 No. 3, pp 288-299.

${ }^{129}$ Homel and Clark, op cit.

${ }^{130}$ Farbstein, J., Wener, R. and Gomez, P. (1979) Evaluation of Correctional

Environments. Washington DC: National Institute of Corrections, Prison Division, U.S. Department of Justice; Suedfeld, P. (1980) Environmental Effects on Violent Behavior in Prisons. International Journal of Offender Therapy and Comparative Criminology. Vol. 24 No. 2, pp 107-116; Wener and Olsen (1980), op cit.

${ }^{131}$ Atlas (1982), op cit; Atlas, R. (1984) Violence in Prison. Environmental Influences. Environment and Behavior. Vol. 16, pp 275-306.

${ }^{132}$ Wortley (1998), op cit.

${ }^{133}$ Clarke (1997), op cit.

${ }^{134}$ Wortley (1997), op cit; Wortley (1998), op cit. 
${ }^{135}$ Wortley (1996), op cit. 